\title{
Social responsibility in a troubled world
}

\author{
Verl Anderson, Ken Kalala Ndalamba and Cam Caldwell
}

\begin{abstract}
Purpose - Social responsibility (SR) in accepting the obligation to resolve the many troubling problems facing tomorrow's generations is essential if those problems are to be effectively addressed. The purpose of this paper is to identify the nature of SR for business, academic institutions, government, religious institutions, and individuals.

Design/methodology/approach - This paper is a conceptual paper which relies heavily on the current literature about social obligations for five major organizations: business, academic institutions, government, religious institutions, and individuals.

Findings - The paper provides the standard of the virtuous continuum and the Hosmer decision-making model to explain why leaders, organizations, and individuals must be more responsible to be perceived as virtuous leaders, complete with 50 examples of action to be taken. Research limitations/implications - As this paper is not an empirical study, it does not present research information.

Practical implications - This paper suggests that organizations can be more effective if they come to understand the responsibilities and stewardship of social responsibilities entrusted to them.

Originality/value - The paper expands on Hosmer's research and incorporates a virtuous continuum in examining the responsibilities of leaders, organizations, and individuals. More importantly, this paper is among the first to identify the specific steps organizations and individuals can take in addressing the challenges and problems facing the world of in key aspects of society.

Although Nobel laureate Economist, Milton Friedman famously declared that "(t)he social responsibility of business is to increase its profits," both the context of his comment and the need for organizations to rethink their role in society have changed markedly since Friedman opined in his 1970 New York Times article. A growing list of experts has recognized that social responsibility (SR) demands that stakeholders become "owners and partners" in resolving the social, economic, and political chaos that exists in a world that continues to be reeling from a seemingly unending stream of gut-wrenching world problems (Steuver, 2016). Moral obligations have been examined, but the analysis of different organizational types is unique. In this paper we acknowledge that business has a corporate citizenship obligation, and suggest that this SR obligation also extends to institutions of all types and to individuals as well.
\end{abstract}


The purpose of this paper is to examine the moral obligations and SR of the leaders of businesses, governments, universities, and individuals as critical stakeholders - stakeholders that are now and will continue to be profoundly affected by problems that have been clearly identified but poorly addressed by public officials, business leaders, university administrators, and other decision makers over the past three decades (Reich, 1998, 2012). We begin by defining SR and presenting that moral duty within the context of today's pressing world problems. We describe the nature of moral responsibility and apply a virtuous continuum that we suggest that today's leaders should adopt - incorporating the moral decision-making model developed by the University of Michigan's La Rue Hosmer (2011). Along the way we propose 50 action steps which individuals and leaders of various types of organizations can consider in confronting the broad array of problems facing the world of today and tomorrow and suggest eight testable hypotheses related to these action steps. We conclude this paper by identifying five contributions of this paper and suggest opportunities for additional research.

\section{Defining SR}

The self-interest focus of many institutions and leaders and reflects a decline in altruism, a concern for personal security, and a tendency to focus on salient and proximate factors when external threats arise (cf. Jones, 1991). Along with Jones (1991) and other scholars (cf. Mitchell et al., 1997; Sonenshein, 2007), we suggest that this tendency to focus internally, and to discount moral responsibilities that are neither immediate nor that affect a closely related individual or group immediately are the common responses of individuals and organizations. This natural tendency to ignore the long-term implications of problems fails to honor moral obligations that exist at institutional and individual levels. We define SR as the moral obligation to identify and actively engage in resolving the present and future critical problems facing the world community in acting as a responsible global citizen.

In his discussion of stakeholder theory, Freeman (1984) explained that organizations owe a complex set of often overlapping but sometimes conflicting duties to stakeholders. Ethicists and scholars have long argued that businesses owe society a much broader set of economic, political, and moral duties than to simply produce quarterly profits for shareholders (Solomon, 1992). More than 2,000 years ago, the Greek city-states required that every business entity must first demonstrate that it could provide a benefit to society before it was to be granted the right to conduct business, and the concept of the welfare of the entire society was a well-accepted concept (Manville and Ober, 2003).

In business, corporate social responsibility (CSR) encompasses a firm's discretionary actions intended to benefit society and reflects the growing expectation that businesses have a moral obligation to share in the mitigation of social, economic, environmental, and political problems facing society at large (Mishra and Modi, 2016). Freeman (1984) explained that CSR acknowledged the needs of all stakeholders to work together in a cooperative effort to optimize value creation for the firm and for the entire community.

Aguinis and Glavas (2012) note that CSR is a profoundly complex obligation encompassing underlying analysis of purpose, disparate mechanisms, and differences in 
perspective about the priority of outcomes. In practice, many firms argue that they are financially unable to engage in any other activities beyond economic survival and profit taking. However, Solomon (1992) opined that a firm's responsibility transcended wealth creation and required firms to be contributing corporate citizens as a fundamental moral obligation. Although shareholders reasonably deserve a return on investment for their contribution wealth in society, the compelling problems facing the world of tomorrow also require that businesses share in the responsibility to serve the public good and resolve problems which hang heavily over the heads of tomorrow's generations (cf. Solomon, 1992). This obligation to be problem-solving stakeholders applies not only to business but also to all types of institutions, organizations, and individuals in society and encompasses the fundamental nature of stakeholder SR. Nonet and Selznick (2002) confirm that government's roles include providing services which promote the public's health, safety, and welfare - including the regulating of programs and services provided by others that have a public impact. In general, government's role tends to be reactive in response to public demands - despite the fact that taking that reactive position frequently results in the deterioration in the quality of life of substantial groups of society until conditions have become intolerable. Thomas Friedman (2009, Ch. 1) is one of many scholars who has been sharply critical of government's failure to be more proactive in identifying and anticipating problems - citing its horrific failures in addressing the 2008-2009 worldwide fiscal crisis and its lack of timely responsiveness to the growing environmental issues associated with dependence upon fossil fuels.

Other scholars have also been critical of the failures of the academic community in addressing practical solutions to common problems (Pfeffer and Fong, 2002; Mintzberg, 2005) and the relative ineffectiveness of colleges and universities in partnering with government and the private sector to address practical solutions (Caldwell, 2014). Ironically, despite repeated criticisms of colleges and universities to restructure old models of thinking, academic decision makers tend to focus on self-gratifying theoretical research of little practical value to practitioners and partnerships between academics and practitioners is typically infrequent - even at many of the "best" academic institutions (Bennis and O'Toole, 2005). The ongoing pressure to "publish or perish" prompts many faculty members to focus on publishing in top-tier academic journals rather than improving the quality of or practical application of classroom teaching (Booker et al., 2008). The result is that many universities fail to practice what they teach (Caldwell et al., 2005). Even highly touted accreditation bodies are guilty of a failure to focus on moral issues. For example, the Academy for the Advancement of Collegiate Schools of Business does not require its accredited business schools to teach a stand-alone business ethics course - despite the fact that deterioration of public trust in leaders is low worldwide and illegal, dishonest, and corrupt practices are rampant in governments throughout the world - and convincing evidence has been presented that teaching ethics "through the curriculum" is ineffective (Swanson and Fisher, 2010).

Religious institutions have frequently acknowledged their SR obligation, as evidenced in the mission and vision of the World Council of Churches - although many local congregations focus inwardly rather than on their role as citizens of the larger community. Religious training of congregants is often focused on doctrines, rituals, and traditions rather than on service to others. The focus in many faiths tends to be on establishing an identity within one's religious group, rather than as a 
citizen of a global community. The external focus, or the acknowledgment of the brotherhood of men, is well expressed by Tutu (2011) who explained the vision of the Ubuntu philosophy - umuntu ngumuntu ngabantu - meaning that a person is a person through other persons. Other insightful religious leaders shared this vision in different words, but with similar intent. Martin Luther King Jr expressed his vision of a world in which all men lived as brothers in his famous "I have A Dream" speech (Carson et al., 2001).

Personal social involvement and engagement as an active member of society was identified by Putman (2001) as a declining phenomenon with a predictable negative impact on each succeeding generation's ownership of societal problems and their willingness to volunteer. The research evidence confirms that many individuals tend to focus on acquisitions and their personal quality of life and the ability to accurately view the nature and causes of worldwide problems is frequently limited by a self-centered focus (cf. Friedman, 2009). Personal SR for the growing global problems facing society often seems beyond the reach of individuals particularly when economic well-being has declined in the wake of the 2008-2009 fiscal crisis and society.

\section{Identifying the moral standard}

Historically, Herbert Simon (1997) explained that decision makers typically overlook superior options and are content with what he labeled as "satisficing" - or choosing from among a small group of quickly identifiable options to identify a solution that simply improves a current situation. Lincoln and Holmes (2011) explained that moral decision making involved a series of steps in which an individual became acquainted with a moral problem, identified its impacts, and ultimately decided to take action. Cameron (2011) has effectively argued that responsible leadership is virtuous leadership that pursues a higher quality of life and flourishing conditions. Simply "satisficing" fails to honor the moral duties that now face leaders and organizations in a world where the consequences of sub-par decisions have profound economic, political, social, and moral consequences (cf. Hosmer, 2011).

In considering the moral standard for leadership responsibility, Lennick and Kiel (2011) explained that the impacts of moral decisions should do no harm, create value in the short term, and create value in the long term. In framing a model for moral decision making, La Rue Hosmer (2011) emphasized the need for leaders to clearly articulate the precise and complete nature of the moral problem; the costs and benefits of alternative approaches to be considered; the ethical, legal, and economic implications of options; and the vital importance of explaining why and how an adopted solution has been undertaken, moral decisions are results of a process which involves both the naming and framing exercise of "moral" issues. Hosmer's model is explained in Figure 1.

Caldwell et al. (2015) built upon the work of Cameron (2003, pp. 185-194) and Carroll and Buchholtz (2014) to establish a virtuous continuum - a standard for measuring leadership behavior that integrates the moral position of these scholars, raises the bar for moral decision making far beyond "satisficing," honors moral outcomes consistent with the standards suggested by Lennick and Kiel (2011), and fits well with the Hosmer (2011) model with regard to the leader's 
obligation to explain his or her decision process. Distinguishing four levels of moral conduct, this virtuous continuum is presented as Figure 2.

Consistent with this virtuous continuum, we advocate that leaders and organizations have the moral responsibility to search for solutions that optimize positive long-term outcomes, effectively use resources, contribute to value creation, minimize negative outcomes, and best serve stakeholders and the larger community. We acknowledge that this virtuous standard is a high standard that many would argue is not practical but concur with Cameron (2011) that the search for morally superior outcomes is nonetheless the obligation of leaders in addressing the troubling problems of the modern world and a fundamental requirement of all SR.

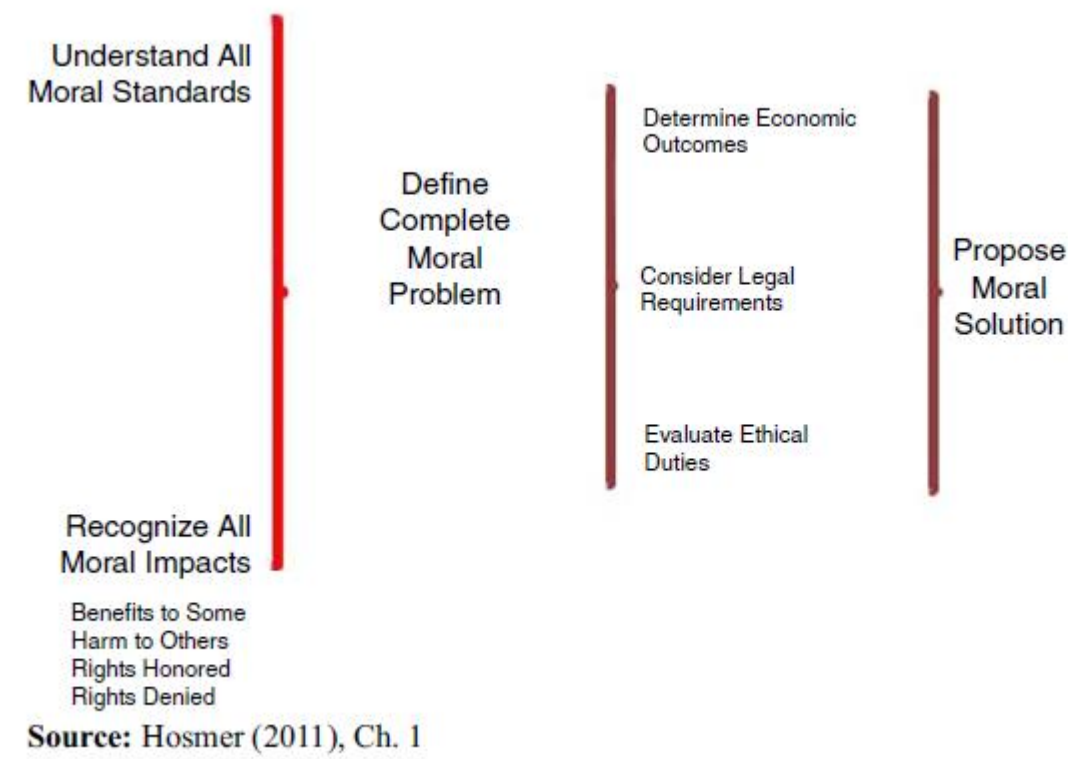

Figure 1. Hosmer's decisionmaking model

We note that this same perspective is shared by other scholars (cf. Covey, 2011). We quickly note, as well, that optimization of outcomes must be focused on the long-term benefit of stakeholders - sometimes appearing to be a compromise rather than a maximization when collaborating and cooperating builds trust and facilitates long-term outcomes (Pava, 2016).

\section{Action steps for business}

In this section, we identify the contributing role of business in perpetuating the diverse problems confronting modern society in both the developed and developing world. We also suggest ten specific action steps to involve business in becoming a more active partner in mitigating those problems and offer our first proposition associated with those action steps. Increasingly, SR has been acknowledged to be an obligation of the business community and has acknowledged that business and commerce have often been a root cause of economic, environmental, health, and social problems that impact the modern world. Friedman (2009) and Lowenstein (2011) are two of many scholars who have tracked the missteps of Wall Street, the big banks, insurance companies like American International Group (AIG), the mortgage companies that perpetuated 
the 2008-2009 worldwide fiscal crisis, and the individuals who obtained mortgages on houses they could not afford. Friedman (2009, p. 17) observed the following:

(T)he whole system depended upon people who originated the risk profiting from that origination, then transferring that risk to someone else and never having to be responsible for it afterward. So people who never should have been taking out mortgages took them out, people who never should have granted them granted them, people who never should have bundled them bundled them, people who never should have rated them AAA rated them AAA, people who should never have sold them to pension funds and other financial institutions worldwide sold them. And companies that never should have been insuring them, like AIG, insured them, without setting aside sufficient assets to cover a massive default. Everyone just assumed they could profit personally in the short term and never have to worry what happened in the long term after they passed them along.

The consequences of this short term, self-serving, and high risk thinking created a domino effect that eventually spawned a worldwide financial crisis that profited a few but that mortgaged the future for literally millions of people in nations around the world (Friedman, 2009). Unfortunately, the greed that fostered the horrific economic and social outcomes of the 20082009 fiscal crisis was the product of leaders adopting a technically legal amoral position on the virtuous continuum. Our first proposition reflects the consequences of the amoral position:

P1. Firms that adopt technically legal but amoral position on the virtuous continuum fail to optimize outcomes resulting in a net loss to society long term.

There are a multitude of examples of individual leaders and firms that technically comply with the law but that create negative outcomes for society. The employment-at-will doctrine, the law that governs employer-employee relationships in 40 of the 45 states in the USA, is an excellent example of a legal but morally questionable human resource management policy that allows employers to terminate employees not protected by a contractual relationship or public interest with or without cause - or for a bad cause.

\begin{tabular}{|c|c|c|c|c|}
\hline & Virtuous & Moral & Amoral & Immoral \\
\hline $\begin{array}{l}\text { Figure } 2 . \\
\text { The virtuous }\end{array}$ & $\begin{array}{l}\text { Seeks to optimize } \\
\text { long-term value } \\
\text { creation and } \\
\text { magnifies duties } \\
\text { owned to all } \\
\text { stakeholders }\end{array}$ & $\begin{array}{l}\text { Adds value, keeps } \\
\text { commitments to } \\
\text { stakeholders and } \\
\text { society, and obeys } \\
\text { laws }\end{array}$ & $\begin{array}{l}\text { Avoids breaking the } \\
\text { law but may act } \\
\text { with self-interest } \\
\text { rather than } \\
\text { society's }\end{array}$ & $\begin{array}{l}\text { Seeks outcomes } \\
\text { that maximize } \\
\text { self-interest and } \\
\text { avoid self-harm }\end{array}$ \\
\hline
\end{tabular}

Pfeffer (1998) explained that this employment policy destroyed trust with employees and reduced employee commitment and creativity - resulting in lost profits and lowered productivity.

Rather than adopting an amoral ethical position, we suggest that leaders and organizations in the private or business sector consider adopting the following programs

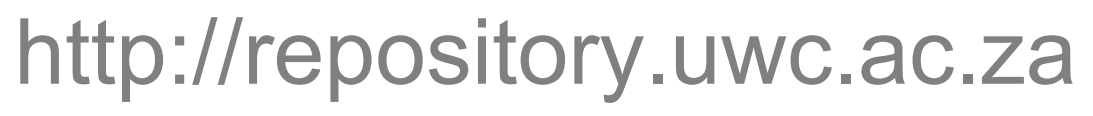


and policies that are exponentially more consistent with the virtuous position on the virtuous continuum:

1. restructure employee retirement programs to provide financial incentives for employees who, upon retirement, engage in any of several public service options that address high priority local and/or global issues identified by the company (Cahn, 1992);

2. create sabbatical opportunities for qualified employees interested in engaging in one-year or six-month public service assignments identified by the company at half-pay after employees work for their company at least six years (Kim et al., 2005);

3. establish business-university partnerships with scholars to identify and research projects to improve firm productivity and profitability and enable those scholars to publish their findings for the public benefit (Seitanidi and Crane, 2014);

4. create job exchange programs with local and foreign colleges and universities for qualified employees to function as "Executives in Residence" at those colleges and universities, while qualified faculty serve in a "Scholar in Residence" position working to improve the functioning of the local business on a mutually agreed upon basis (Hom et al., 2009; Altbach and Teichler, 2001; McDermott et al., 1996);

5. create job exchange programs with appropriate governmental agencies and school districts for qualified employees to function as business practitioner resources, while qualified school district and governmental employees serve as business interns for the local business on a mutually agreed upon basis (Brooks et al., 2007);

6. provide scholarships for highly qualified student interns in exchange for those outstanding students working full-time during the summers and after graduation for the employer for a mutually agreed upon salary and fixed time period (Brooks et al., 2007);

7. fund "skunk works" entrepreneurial projects in partnership with local college and university student or faculty entrepreneurs to explore creative research and development projects of mutual interest to the business and those entrepreneurs (Binks et al., 2006);

8. create "micro-loan" programs administered similar to the Grameen Project to fund entrepreneurial and cottage industry projects in "adopted" communities across the globe (Chesbrough et al., 2006; Bhatt and Tang, 2001);

9. incorporate "Involvement in Social Responsibility" activities as a required performance assessment goal of every employee in their organization and empower employees to engage in 40 hours per year of documented SR activities for agreed upon projects with full pay (Peloza and Shang, 2011; Burke and Logsdon, 1996); and

10. adopt employee wellness programs which share cost savings with employees for health care reduction costs resulting from smoking cessation, weight loss, personal fitness, and other wellness activities (Baicker et al., 2010; Berry et al., 2010; Osilla et al., 2012; Naydeck et al., 2008).

These ten proposals are simply examples of possible business initiatives that reflect the virtuous position on the virtuous continuum. The important issue is that many programs like these ten examples can be adopted by local businesses and can mutually benefit the businesses, their shareholders, and society - especially if governmental units were to provide tax incentives for businesses who adopted such programs. 


\section{Actions steps for academia}

In this section we identify challenges facing colleges and universities in expanding their capacity to address pressing problems facing the world. We include a proposition about the degree to which colleges and universities currently meet the criteria of the virtuous continuum and also suggest ten more specific examples of action steps in which those academic institutions can contribute to the practical problems facing society.

Colleges and universities have been periodically criticized for an "ivory tower" approach to practical issues and "their academic" has come to mean that a proposal is to be dismissed as irrelevant, and theoretical with minimal real world value (Caldwell and Jeane, 2007). For example, Pfeffer and Fong (2002) suggested that business programs at both the graduate and undergraduate levels lacked effectiveness and Mintzberg (2005) has criticized much of the academic community for its failure in teaching students about practical concepts that are key to the success of organizations.

There are many cases of universities partnering effectively within their communities or with government or business to conduct significant research - both practical and theoretical. Such efforts are not to be minimized and are to be commended as the prototypes for expanded efforts. At the same time, there are opportunities to expand this role to geometrically and exponentially increase the incidence of academic institutions playing a major role in addressing the critical problems of productivity, efficiency, and quality in business and education - as well as environmental, social, public health, and a host of other global issues that must be addressed.

The activities of many colleges and universities in making incremental contributions to the quality of life of their communities and the extent that they engage in practical research in partnership with government or the private sector meets the requirements of moral behavior on the virtuous continuum. However, the contributions of colleges and universities fail to optimize the great potential value of these institutions and, therefore, lead to our second proposition:

P2. Colleges and universities that adopt the moral position on the virtuous continuum but fail to optimize financial, social, and other ethical outcomes make contributions that do not honor their much greater potential benefit to society.

The following are examples of programs which colleges and universities could take that would expand their capacity to contribute to the public welfare and help to address present and future troubling problems facing the world:

1. establish service learning requirements for every student, requiring each student to engage in a minimum number of service learning hours benefiting the local or international community as a requirement for graduation (Austin et al., 2000; Eyler et al., 1997; Bringle and Hatcher, 1996; Jacoby, 1996);

2. involve faculty members in a major service learning project associated with his/her academic field and recommend that the service learning project result in a 
scholarly publication as a requirement for obtaining academic tenure and promotion (Jacoby, 1996; Austin et al., 2000; Bringle and Hatcher, 1996; Eyler et al., 1997);

3. encourage and support faculty members to spend their sabbatical addressing either a problem being faced by a third-world country, a major problem affecting their local community, an issue benefiting a major local employer, or a similar project acknowledged as contributing in a practical way to the quality of life of society (Nelson, 1976);

4. create online and/or hybrid doctoral programs for Native Americans, African Americans, and Hispanics or other minority groups who currently make up substantial portions of the national and/or local population to provide opportunities for those persons to become role models for tomorrow's citizens within their ethnic groups (Summers, 2006);

5. partner with government agencies, school districts, and/or the business community to engage in mutually agreed upon environmental, social, political, or economic problems identified as high priorities impacting their local or national communities;

6. participate in faculty exchanges with colleges or universities in other countries to increase understanding of other cultures, to provide local faculty with the opportunity to assist those other countries in addressing their local problems, and to provide international experiences in service learning for local students accompanying those faculty (Hom et al., 2009; Altbach and Teichler, 2001; McDermott et al., 1996);

7. engage students in externships in other nations as resources to businesses, governments, local communities, and universities as an opportunity for those students to become more familiar with the problems of the international community and to engage in service learning and/or professional development activities in those other nations (Brooks et al., 2007);

8. encourage and support faculty to increase their focus on experiential learning that emphasizes the need to address real world problems, rather than overemphasizing publishing in top-tier academic journals that focus primarily on academic theory with little practical relevance for society and provide professional recognition and other intrinsic incentives for faculty who model those behaviors (Heath and Trygstad, 2016; Morris, 2016);

9. work in partnership with government, the business community, and other motivated groups to create prestigious tenured chairs for faculty who demonstrate the unusual capacity to address and resolve social, economic, political, or financial problems facing the local, national, or international community; and

10. expand involvement of the university in the local K-12 educational systems within their local communities or in neighboring communities (particularly the inner cities) where educational systems are in need of special help to improve the literacy and/or academic performance of low performers (Boaz, 1990).

As in the case of the business proposals, these suggestions simply represent examples of opportunities for colleges and universities to expand their role in addressing the troubling issues that face local, national, and international communities - issues that all indicators suggest will only become more difficult to resolve in the decades ahead. 


\section{Action steps for government}

In this section we identify the need for governments at the local and national level to expand their capacity to resolve the gnawing problems facing society - typically by partnering with other major institutions and individuals in supporting integrated efforts to identify and address those problems and their root causes. This section also includes three propositions associated with the roles of government in the important effort of solving these problems. In addition, this section suggests ten examples of government action steps that can help rectify ethical, economic, social, political, and environmental problems.

Like most other institutions, governments and elected leaders have suffered by extensive public criticism and profound distrust (Stevenson and Wolfers, 2011). Political leaders are routinely charged with corruption and dishonesty in many of the nations throughout the world. In the USA, political leaders struggle to earn public trust, as plainly evidenced by the 2016 presidential election in which both of the major candidates were negatively perceived by more than half of the electorate. In Africa and other places, leaders have sought to stay in power beyond the term limit stipulated in the countries respective constitutions which they manipulate through "referendums" in their favor to justify their continuity in office (Gaffey, 2015).

Although many elected and appointed officials are well regarded and contribute substantially to the public good, "politics" is nonetheless perceived to be "a dirty word" in the minds of many people - and unfortunately, in many cases it has earned that reputation. Our third proposition addresses the negative light in which government activities are often viewed, but suggests that this negative image can be vastly improved and meet the requirements of the virtuous continuum:

P3. Government leaders that demonstrate integrity and competence in their ability to address local, national, and international problems will be perceived as more virtuous on the virtuous continuum than government leaders that do not demonstrate those qualities.

Although the burden of taxes is typically viewed in a negative light by many of the residents of communities, taxes that are viewed as equitable and that are identifiable as useful in addressing important public needs are likely to be viewed less unfavorably than other taxes. As Hosmer (2011) has noted, the actions of decision makers tend to be more likely to be approved when the rationale for decisions has been clearly communicated - including an explanation of the costs and benefits of decisions on stakeholders. Consistent with this discussion of tax-related decision making, we also suggest our fourth and fifth propositions:

P4. Governments that adopt tax systems that provide tax break incentives for addressing earmarked local, national, and world problems will be viewed as more virtuous on the virtuous continuum than governments that do not put in place such a tax system.

P5. Governments that explain the rationale for whom those taxes will benefit, how the tax burden will be shared, and that provide tax break incentives for addressing earmarked

\section{http://repository.uwc.ac.za}


local, national, and world problems will be viewed as more virtuous on the virtuous continuum than governments that do not put in place such a tax system.

As with business and academic institutions, we provide ten more examples of possible ways in which governments at the local, state, or national level can initiate projects and programs which reflect a virtuous commitment to addressing major problems facing their local, national, or global communities:

1. create tax incentives which credit businesses or individuals for their investment in service projects, research, or other earmarked activities that measurably improve quality of life or mitigate problems facing the local, national, or global community and allow them to defer the costs associated with those projects or activities (Reich, 1998);

2. increase the process of monitoring socially, economically, environmentally virtuous and detrimental individual and business conduct and create public interest committees which propose sanctions for those who exacerbate existing problems and support for those who mitigate and/or effectively address those problems;

3. create a tax system that fairly assigns user costs for products created by multinational corporations that have relocated to avoid their fair share of a tax burden reasonably assigned to them as world citizens and for their contribution to economic, environmental, and/or political problems (Reich, 1998);

4. develop and engage in exchange programs for talented government employees with comparable positions in the private sector, in academia, or in other relevant environs to acquaint government employees with the perspectives of those organizations and for employees of those organizations to more fully understand government issues (Hom et al., 2009; Altbach and Teichler, 2001; McDermott et al., 1996);

5. revise and update regulations governing political contributions, lobbying, election financing, and the employment of retired or defeated elected officials to create more restricted and more transparent laws prohibiting the undue influence of business in the political process (Kim et al., 2005);

6. increase exponentially taxes and fees charged to companies engaged in the manufacture, distribution, or sale of military weapons or goods identified as products to be used by military groups;

7. formalize and fund at local, regional, state, national, and global levels review bodies composed of representatives from diverse highly respected citizens' groups to function as fully empowered oversight groups, staffed by technical expert resources, to evaluate SR programs, publicize successes achieved and lessons learned, and advise participating organizations and the general public in fine tuning efforts to address these problems;

8. increase grant funding for collaborative research between business and industry associated with the resolution of local, regional, national, and world issues, monitored by citizen's groups to ensure that time-targeted goals are achieved and that those goals meaningfully contribute to the mitigation of those problems (Cobb, 2002);

9. restructure grants and loans made to foreign countries to require those recipients to meet human rights standards, to ensure that monies contributed are used and matched to achieve economic and environmental goals, and to create citizen monitoring groups to 
evaluate the appropriate use of and outcomes achieved by those monies if continued funding is to occur (Mitlin, 1993; Cobb, 2002); and

10. create forums to engage with communities at local levels to deliberate on various issues affecting them directly at which solutions can be found at their level with their direct involvement and participation as a way of empowering the community.

\section{Action steps for religious institutions}

In this section we identify opportunities for religious institutions to expand their efforts to serve society by broadening their SR role to include significantly more local and global citizenship activities. We also propose a sixth proposition and list ten examples of actions that religious institutions can initiate to expand their SR contribution.

Rumambi et al. (2014, p. 24) summarize the SR of the Christian perspective as encompassing the pursuit of "human dignity, common good, solidarity, and social justice." Although many religious institutions embrace this SR citizenship role as part of their institution's moral responsibility, the need to improve the quality of life of those who are in need is well established in holy writ. For example, for the Christian faiths, Biblical language affirms that actions must accompany kind words or are only of limited value to others who have a compelling need (cf. Holy Bible, James 2, pp. 15-16). The mandate to honor one's duties to others, to be a good citizen, and to help to create a better world is an essential and fundamental underlying perspective of many religious faiths - Christian and non-Christian (Boyett, 2016).

Although religious institutions are highly moral in many respects, we suggest our sixth proposition:

P6. Religious institutions that adopt and actively participate in expanded programs earmarked to address local, national, and world problems will be viewed as more virtuous on the virtuous continuum than religious institutions that do not adopt and actively participate in such programs.

The following are ten examples of ways in which religious institutions can expand their role in addressing highly important local, state, national, and global world problems:

1. create service mission programs that encourage and/or "call" local congregants with special interests or talents to serve missions to specifically benefit those in need in third world countries or to address critical world problems (Westad, 2005; Dupuis, 2004);

2. partner with inner-city school districts and provide volunteers to assist in providing tutoring, counseling, music and art classes, classroom assistance, and other needed services for underfunded schools (Dauber and Epstein, 1993);

3. establish high quality day care, summer school, after school programs, and skill training programs for communities where those services are badly needed and/or where those community resources are difficult to fund (Berger and Black, 1992; McCartney et al., 2007); 

senior population and integrate those programs with government nutrition, health care, and education programs to serve the needs of this important sector of society (Fiscella et al., 2000);

5. co-sponsor family, marriage, anger management, and mental health counseling programs to serve underserved communities in partnership with skilled practitioners, hospitals, and government agencies (Kassinove and Tafrate, 2002);

6. plant and maintain community gardens, build pocket parks, and partner with local community groups in low-income areas where these amenities are unavailable to local residents but can positively impact quality of life and enhance individual and community self-esteem and self-efficacy (Twiss et al., 2011);

7. raise money to fund sanitation, water system, and/or other badly needed public works projects to improve the living conditions of third-world communities that lack such basic services and involve local congregants in the actual work involved in constructing those systems (Berger, 2004; Moore, 2004);

8. conduct educational programs in partnership with local K-12 and university school systems within schools and co-sponsor service projects involving those students in addressing the needs of underserved, low-income, or underprivileged individuals and groups (Marín et al., 1995);

9. create and fund scholarships to fund the education of talented young local congregants that would have limited opportunities to obtain high quality educations, or that seek careers identified as meeting high priority needs associated with pressing world problems (Eyal and Bärnighausen, 2012); and

10. challenge local congregants on a weekly basis to look for opportunities to live their religions and practice what they believe and deliver worship service sermons and weekly religion class curricula that reinforces for each age group the translation of religious principles into practice on a daily basis.

We acknowledge that examples on this list are already being done in some congregations throughout the world but provide this list as opportunities for virtuous service that fit well with the virtuous continuum and demonstrate the pursuit of optimal outcomes that serve stakeholders by meaningfully addressing compelling needs.

\section{Action steps for individuals}

In this section we examine the roles that individuals can assume to demonstrate SR to create a world which more effectively addresses common problems facing society. In this section we also identify ten examples of individual conduct and suggest two more propositions.

Albert Schweitzer, Mahatma Gandhi, and Mother Teresa of Calcutta quickly come to mind as individuals whose lives were role models and a message of love, service, and compassion for others. Each of those individuals inspired hope, improved the human condition, and touched thousands of lives. As Covey (2011) has noted, people like this have "found their voice and enabled others to also find theirs." It is in discovering our greatness, whether as individuals or as organizations, that we achieve the standard of virtuousness 
that we each have the potential to fulfill. Notwithstanding our great capacity, each of us also knows that we often underperform and get distracted from achieving our highest potential. Consistent with this very human phenomenon, we present our seventh and eighth propositions:

P7. Individuals who actively participate in programs earmarked to address local, national, and world problems will be viewed as more virtuous on the virtuous continuum than individuals who do not adopt and actively participate in such programs.

P8. Individuals who actively participate in programs earmarked to address local, national, and world problems will be viewed as more ethical leaders than individuals who do not actively participate in such programs.

The following is a list of examples of ways in which individuals may actively engage to mitigate significant local, regional, state, national, or global problems:

1. volunteer to assist a local or inner-city school district where student performance is below national standards and tutor individual students who are struggling academically (Epstein and Dauber, 1991);

2. organize, help to fund, and/or participate in a community project to build or repair a home for deserving elderly and/or financially struggling individuals along the lines of Habitat for Humanity (Marshall, 2004);

3. serve on a board, commission, or committee earmarked to study, resolve, or monitor a major community problem and make a significant contribution in helping that group to excel in achieving its stated purpose (Minkler and Wallerstein, 2005; Angela and Rutherford, 1990).

4. raise funds for or substantially contribute to a well-managed fund raising project to assist third world country individuals to upgrade their quality of life (Sensoy and Marshall, 2010);

5. establish a personal mission statement and realistic action plan to personally engage in one or more significant projects associated with improving the human condition, make a personal commitment to complete that plan, and take the requisite steps to make it a reality (David and David, 2003; Mullane, 2002; Jones, 1998; Morrisey, 1992; Campbell and Yeung, 1990); 6. earmark a portion of a life insurance benefit to support a project that meaningfully addresses a major community or global problem;

7. sponsor or financially assist those in need (e.g. a third world family) or individual to assist that person to obtain an education and improve their quality of life;

8. study and research a major community, regional, state, national, or global issue and actively participate in discussions with decision makers and other key individuals to develop practical ways to mitigate that problem;

9. assess your own personal and family life and take responsibility for improving your own role in contributing to local or other world problems; and

10. identify an issue in which you have a strong personal interest, research who is also engaged in addressing that issue, and partner with other individuals or organizations engaged in mitigating that problem. 
Once again, items on this list are already being done by some individuals throughout the world but we provide these examples as opportunities that enable individuals to be more productive in honoring their SR role in a troubled world.

\section{Contributions of this paper}

SR in taking ownership for the challenges and problems facing the world of tomorrow must become the moral responsibility of organizations and individuals in all facets of life and in all sections of society if our children and grandchildren are to live in a world that is environmentally healthy, fiscally sound, politically secure, and socially connected. Just as we harvest the benefits of others who have come before us, we each owe fundamental duties to those who inherit both the benefits and problems that we create. In addressing the importance of becoming stakeholders in working together to address the problems of a troubled world, this paper makes five meaningful contributions:

(1) It defines SR as a universal obligation: SR acknowledges the common brotherhood of mankind and the obligation of every business, college or university, government, religious institution, and individual to take personal responsibility for creating a better world and for mitigating the problems facing future generations (Friedman, 2009).

(2) It clarifies the ethical responsibility of decision making: Each individual plays a leadership role to the degree that (s)he seeks to work in partnership with others to achieve shared goals. The ethical decision-making model of La Rue Hosmer (2011) is a valid tool for each of us to self-assess our decisions and choices in using our resources to create a better life for ourselves and for others.

(3) It suggests eight propositions associated with SR and the virtuous continuum: in framing these propositions, the paper identifies the importance of individuals and organizations carefully reevaluating their missions, choices, and responsibilities.

(4) It incorporates the virtuous continuum as a higher standard for SR: Although many groups and individuals are outstanding examples of virtuous choices, each organization and individual has the responsibility to assess their own choices with this virtuous continuum to identify how they can raise the bar for themselves in honoring their obligation to the community of man.

(5) It identifies 50 examples of virtuous choices, demonstrating that a multitude of virtuous activities are not only available and needed but documenting that these examples are already being undertaken by others: in so doing, this paper not only encourages others to emulate outstanding virtuous examples but provides specific ways in which individuals and organizations can become more virtuous and more responsible actors.

\section{Conclusion}

In writing about the obligations of responsible leadership, Kim Cameron (2011), a world-class scholar from the University of Michigan, has explained that leaders have a moral obligation to create a flourishing world - equating responsible leadership and virtuous leadership. As the model of ethical decision making that Hosmer (2011) affirmed, leaders who seek to be perceived as credible have the obligation to thoughtfully assess the moral problems that confront them, assess the nature of the positive and negative outcomes of options, identify the alternative that

\section{http://repository.uwc.ac.za}


best honors duties owed to others, and explain in clear terms their rationale used in making decisions.

Moral decisions that optimize value creation, honor duties made to stakeholders, minimize ancillary negative impacts, and improve the quality of life of society are not only ethically rich but both virtuous and responsible. Peter Drucker (1993), often called "the founder of modern management," observed that "(l)eadership is lifting a person's vision to higher sights, the raising of a person's performance to a higher standard." The challenge of SR is for each individual, leader, and organization - regardless of its nature or type - is to contribute to creating a world that enriches, enhances, and lifts themselves and others to that vision of higher sights and that performance to a higher standard that Drucker envisioned. 


\section{References}

Aguinis, H. and Glavas, A. (2012), "What we know and don't know about corporate social responsibility: a review and research agenda", Journal of Management, Vol. 38 No. 4, pp.932-968.

Altbach, P.G. and Teichler, U. (2001), "Internationalization and exchanges in a globalized university", Journal of Studies in International Education, Vol. 5 No. 1, pp. 5-25.

Angela, F. and Rutherford, J. (Eds) (1990), Identity: Community, Culture, Difference, Lawrence and Wishart, London, pp. 9-27.

Austin, A.W., Vogelgesang, L.J., Ikeda, E.K. and Yee, J.A. (2000), "How service learning affects students”, Higher Education, Vol. 144 No. 1, Digital Commons at University of Nebraska, Omaha, NB.

Baicker, K., Cutler, D. and Song, Z. (2010), "Workplace wellness programs can generate savings", Health Affairs, Vol. 29 No. 2, pp. 304-311.

Bennis, W.G. and O’Toole, J. (2005), "How business schools lost their way”, Harvard Business Review, Vol. 83 No. 5, pp. 96-104.

Berger, M.C. and Black, D.A. (1992), "Child care subsidies, quality of care, and the labor supply of low-income, single mothers", The Review of Economics and Statistics, Vol. 74 No. 4, pp. 635-642.

Berger, M.T. (2004), "After the third world? History, destiny and the fate of third worldism", Third World Quarterly, Vol. 25 No. 1, pp. 9-39.

Berry, L., Mirabito, A.M. and Baun, W.B. (2010), "What's the hard return on employee wellness programs?”, Harvard Business Review, December, pp. 2012-2068.

Bhatt, N. and Tang, S.Y. (2001), "Delivering microfinance in developing countries: controversies and policy perspectives", Policy Studies Journal, Vol. 29 No. 2, pp. 319-333.

Binks, M., Starkey, K. and Mahon, C.L. (2006),"Entrepreneurship education and the business school”, Technology Analysis and Strategic Managements, Vol. 18 No. 1, pp. $1-18$.

Boaz, D. (1990), Liberating Schools: Education in the Inner City, Cato Institute Publishers New York, NY.

Booker, L.D., Bontis, N. and Serenko, A. (2008), "The relevance of knowledge management and intellectual capital research", Knowledge and Process Management, Vol. 15 No. 4, pp. 235-246.

Boyett, J. (2016), 12 Major World Religions: The Beliefs, Rituals, and Traditions of Humanity's Most Influential Faiths, Zephyros Press, Berkeley, CA.

Bringle, R.G. and Hatcher, J.A. (1996), "Implementing service learning in higher education", The Journal of Higher Education, November, pp. 221-239.

Brooks, S., MacIntosh, S., MacLennan, B. and Thornhill, J. (2007), "A guide to local and international student exchange, volunteer, government programs and scholarships", YA Hotline, No. 78.

Burke, L. and Logsdon, J.M. (1996), "How corporate social responsibility pays off”, Long Range Planning, Vol. 29 No. 4, pp. 495-502.

Cahn, S.M. (1992), Morality, Responsibility, and the University: Studies in Academic Ethics, Temple University Press, Philadelphia, PA. 
Caldwell, C. (2014), "Forging ethics-based business partners: the integration of business, employees, and education", Graziadio Business Review, Vol. 17 No. 1, pp. 1-6, available at: https://gbr.pepperdine.edu/2014/04/forging-ethics-based-businesspartners/

Caldwell, C. and Jeane, L. (2007), "Ethical leadership and building trust - raising the bar for business", Journal of Academic Ethics, Vol. 5 No. 1, pp. 1-4.

Caldwell, C., Hasan, Z. and Smith, S. (2015), "Virtuous leadership - insights for the 21st century", Journal of Management Development, Vol. 34 No. 9, pp. 1181-1200.

Caldwell, C., Karri, R. and Matula, T. (2005), "Practicing what we teach - ethical considerations for business schools", Journal of Academic Ethics, Vol. 3 No. 1, pp. 125.

Cameron, K. (2011), "Responsible leadership as virtuous leadership", Journal of Business Ethics, Vol. 98 No. 1, pp. 25-35.

Cameron, K.S. (2003), "Ethics, virtuousness, and constant change", The Ethical Challenge: How to Lead with Unyielding Integrity, Jossey-Bass, San Francisco, CA, pp. 185-194.

Campbell, A. and Yeung, S. (1990), “Do you need a mission statement?” Vol. 4 No. 1208, Economist Intelligence Unit.

Carroll, A.B. and Buchholtz, A.K. (2014), Business and Society: Ethics, Sustainability, and Stakeholder Management, Cengage Learning Publishers, New York, NY.

Carson, C., Shepard, K. and Young, A. (2001), A Call to Conscience: The Landmark of Dr Martin Luther King Jr, Warner Books, New York, NY.

Chesbrough, H., Ahern, S., Finn, M. and Guerraz, S. (2006), "Business models for technology in the developing world: the role of non-governmental organizations", California Management Review, Vol. 48 No. 3, pp. 48-61.

Cobb, N.K. (2002), "The new philanthropy: its impact on funding arts and culture", The Journal of Arts Management, Law, and Society, Vol. 32 No. 2, pp. 125-143.

Covey, S.R. (2011), The 3rd Alternative: Solving Life's Most Difficult Problems, Free Press, New York, NY.

Dauber, S.L. and Epstein, J.L. (1993), "Parents' attitudes and practices of involvement in inner-city elementary and middle schools", Families and Schools in a Pluralistic Society, State University of New York Press, New York, NY, pp. 53-71.

David, F.R. and David, F.R. (2003), "It's time to redraft your mission statement", Journal of Business Strategy, Vol. 24 No. 1, pp.11-14.

Drucker, P. (1993), Management: Tasks, Responsibilities, Practices, Harper Business Publishers, New York, NY.

Dupuis, C.C. (2004). "Humanitarian missions in the third world: a polite dissent", Plastic and Reconstructive Surgery, Vol. 113 No. 1, pp. 433-435.

Epstein, J.L. and Dauber, S.L. (1991), "School programs and teacher practices of parent involvement in inner-city elementary and middle schools", The Elementary School Journal, pp. 289-305.

Eyal, N. and Bärnighausen, T. (2012), "Precommitting to serve the underserved", The American Journal of Bioethics, Vol. 12 No. 5, pp. 23-34.

Eyler, J., Giles, D.E. Jr and Braxton, J. (1997), "The impact of service-learning on college students", Michigan Journal of Community Service Learning, Vol. 4 No. 4, pp. 5-15. 
Fiscella, K., Franks, P., Gold, M.R. and Clancy, C.M. (2000), "Inequality in quality: addressing socioeconomic, racial, and ethnic disparities in health care", JAMA, Vol. 283 No. 19, pp. 2579-2584.

Freeman, R.E. (1984), Strategic Management: A Stakeholder Approach, Cambridge University Press, New York, NY.

Friedman, M. (1970), The Social Responsibility of Business is to Increase Its Profits, Pearson, New York, NY, pp. 122-124.

Friedman, T.L. (2009), Hot, Flat, and Crowded: Why We Need a Green Revolution - and How It Can Renew America, Picador, New York, NY.

Gaffey, C. (2015), "Africa's third-term problem: why leaders keep clinging to power", Newsweek, December 15, available at: www.newsweek.com/africa-third-term-problemcling-power-403440 (accessed February 10, 2017).

Heath, D. and Trygstad, K. (2016), "Experiential learning for the classroom and beyond", Innovations in Teaching and Learning Conference Proceedings, Vol. 8, July, p. 2.

Hom, P.W, Tsui, A.S., Wu, J.B., Lee, T.W., Zhang, A.Y., Fu, P.P. and Li, L. (2009). "Explaining employment relationships with social exchange and job embeddedness", Journal of Applied Psychology, Vol. 94 No. 2, pp. 277-297.

Hosmer, L.T. (2011), The Ethics of Management: A Multidisciplinary Approach, 7th ed., Richard D. Irwin, New York, NY.

Jacoby, B. (1996), "Service-learning in higher education: concepts and practices", The Jossey-Bass Higher and Adult Education Series, Jossey-Bass Publishers, San Francisco, CA.

James 2, In Holy Bible, pp. 15-16.

Jones, L.B. (1998), The Path: Creating Your Mission Statement for Work and for Life, Hyperion, New York, NY.

Jones, T.M. (1991), "Ethical decision making by individuals in organizations: an issuecontingent model", Academy of Management Review, Vol. 16 No. 2, pp. 366-395.

Kassinove, H. and Tafrate, R.C. (2002), Anger Management: The Complete Treatment Guidebook for Practitioners, Impact Publishers, New York, NY.

Kim, P.S., Halligan, J., Cho, N., Oh, C.H. and Eikenberry, A.M. (2005), "Toward participatory and transparent governance: report on the sixth global forum on reinventing government", Public Administration Review, Vol. 65 No. 6, pp. 646-654.

Lennick, D. and Kiel, F. (2011), Moral Intelligence 2.o: Enhancing Business Performance and Leadership Success in Turbulent Times, Pearson Prentice Hall, New York, NY.

Lincoln, S.H. and Holmes, E.K. (2011), "Ethical decision making: a process influenced by moral intensity", Journal of Healthcare, Science and the Humanities, Vol. 1 No. 1, pp. 55-69.

Lowenstein, R. (2011), The End of Wall Street, Penguin Books, New York, NY.

McCartney, K., Dearing, E., Taylor, B.A. and Bub, K.L. (2007), "Quality child care supports the achievement of low-income children: direct and indirect pathways through caregiving and the home environment", Journal of Applied Developmental Psychology, Vol. 28 No. 5, pp. 411-426.

McDermott, K., Laschinger, H.K.S. and Shamian, J. (1996), "Work empowerment and organizational commitment”, Nursing Management, Vol. 27 No. 5, pp. 44-47. 
Manville, B. and Ober, J. (2003), "Beyond empowerment: building a company of citizens", Harvard Business Review, Vol. 81 No. 1, pp. 48-53.

Marín, G., Burhansstipanov, L., Connell, C.M., Gielen, A.C., Helitzer-Allen, D., Lorig, K. and Thomas, S. (1995), "A research agenda for health education among underserved populations", Health Education and Behavior, Vol. 22 No. 3, pp. 346-363.

Marshall, E. (2004), “Habitat for humanity”, Law Now, Vol. 29 No. 5, pp. 60-72.

Minkler, M. and Wallerstein, N. (2005), "Improving health through community organization", Community Organizing and Community Building for Health, pp. 26-51.

Mintzberg, H. (2005), Managers Not MBAs: A Hard Look at the Soft Practice of Managing and Management Development, Berrett-Koehler Publishers, New York, NY.

Mishra, S. and Modi, S.B. (2016), "Corporate social responsibility and shareholder wealth: the role of marketing capability”, Journal of Marketing, Vol. 8 o No. 1, pp. 26-46.

Mitchell, R.K., Agle, B.R. and Wood, D.J. (1997), "Toward a stakeholder identification and salience: defining the principle of who and what really counts", Academy of Management Review, Vol. 27 No. 4, pp. 853-886.

Mitlin, D. (1993), "Funding community level initiatives", Environment and Urbanization, Vol. 5 No. 1, pp. 148-154.

Moore, D. (2004), "The second age of the third world: from primitive accumulation to global public goods?”, Third World Quarterly, Vol. 25 No. 1, pp. 87-109.

Morris, L.V. (2016), "Experiential learning for All”, Innovative Higher Education, Vol. 41 No. 2, pp. 103-104.

Morrisey, G.L. (1992), "Your personal mission statement: a foundation for your future", Training and Development, Vol. 46 No. 1, pp. 71-75.

Mullane, J.V. (2002), "The mission statement is a strategic tool: when used properly", Management Decision, Vol. 40 No. 5, pp. 448-455.

Naydeck, B.L., Pearson, J.A., Ozminkowski, R.J., Day, B.T. and Goetzel, R.Z. (2008), "The impact of the highmark employee wellness programs on 4-year healthcare costs", Journal of Occupational and Environmental Medicine, Vol. 50 No. 2, pp. 146-156.

Nelson, M.L. (1976), The How and Why of Third World Missions: An Asian Case Study, William Carey Library, New York, NY.

Nonet, P. and Selznick, P. (2002), Law and Society in Transition, Transaction Publishers, New York, NY.

Osilla, K.C., Van Busum, K., Schnyer, C., Larkin, J.W., Eibner, C. and Mattke, S. (2012), "Systematic review of the impact of worksite wellness programs", The American Journal of Managed Care, Vol. 18 No. 2, pp. 68-81.

Pava, M. (2016), “'The art of moral criticism' rebuke in the Jewish tradition and beyond”, The Oxford Handbook of Judaism and Economics, Oxford.

Peloza, J. and Shang, J. (2011), "How can corporate social responsibility activities create value for stakeholders? A systematic review", Journal of the Academy of Marketing Science, Vol. 39 No. 1, pp. 117-135.

Pfeffer, J. (1998), The Human Equation; Building Profits by Putting People First, Harvard Business School Press, Boston, MA.

Pfeffer, J. and Fong, C.T. (2002), "The end of business schools? Less success than meets the eye", Academy of Management Learning and Education, Vol. 1 No. 1, pp. 78-95. 
Putman, R.D. (2001), Bowling Alone: The Collapse and Revival of American Community, Touchstone Books, New York, NY.

Reich, R.B. (1998), "The new meaning of corporate social responsibility", California Management Review, Vol. 40 No. 2, pp. 8-17.

Reich, R.B. (2012), Beyond Outrage: What Has Gone Wrong with Our Economy and Our Democracy, Fix It, Vintage, New York, NY.

Rumambi, H.D., Triyuwono, I., Inanto, G. and Djamhuri, A. (2014), "Love-based corporate social responsibility (CSR): a Christian perspective", International Journal of Business and Behavioral Sciences, Vol. 4 No. 5, pp. 24-42.

Seitanidi, M.M. and Crane, A. (2014), Social Partnerships and Responsible Business: A Research Handbook, Routledge, New York, NY.

Sensoy, Ö. and Marshall, E. (2010), "Missionary girl power: saving the 'third world' one girl at a time”, Gender and Education, Vol. 22 No. 3, pp. 295-311.

Simon, H.A. (1997), Administrative Behavior, Free Press, New York, NY.

Solomon, R.C. (1992), Ethics and Excellence: Cooperation and Integrity in Business, Oxford University Press, New York, NY.

Sonenshein, S. (2007), "The role of construction, intuition, and justification in responding to ethical issues at work: the sensemaking-intuition model”, Academy of Management Review, Vol. 32 No. 4, pp. 1022-1040.

Steuver, H. (2016), "Hank Stuever column”, The Washington Post, September 22, p. 6.

Stevenson, B. and Wolfers, J. (2011), "Trust in public institutions over the business cycle", The American Economic Review, Vol. 101 No. 3, pp. 281-287.

Summers, M.F. and Hrabowski, F.A. III (2006), "Preparing minority scientists and engineers", Institutions, Vol. 17 No. 18.

Swanson, D. and Fisher, D. (2010), Toward Assessing Business Ethics Education, Vol. 6, Information Age, Charlotte, NC.

Tutu, D. (2011), God is Not a Christian, Rider Books, Johannesburg.

Twiss, J., Dickinson, J., Duma, S., Kleinman, T., Paulsen, H. and Rilveria, L. (2011), "Community gardens: lessons learned from California healthy cities and communities", American Journal of Public Health.

Westad, O.A. (2005), The Global Cold War: Third World Interventions and the Making of Our Times, Cambridge University Press, Cambridge.

\section{Further reading}

Bennis, W.G. and Nanus, B. (2007), Leaders: Strategies for Taking Charge (Collins Business Essentials), Harper Business Publishers.

Hannan, M.T. and Freeman, J. (1984), "Structural inertia and organizational change", American Sociological Review, pp. 149-164.

King, C.S. and Zanetti, L.A. (2005), Transformational Public Service: Portraits of Theory in Practice, M.E. Sharpe Publishers, New York, NY.

Labour Research Department (1992), "Bargaining report”, Nos 113-134, Cornell University, New York, NY.

Osborne, D. (1971), "The use and promotion of science in developing countries", Minerva, Vol. 9 No. 1 , pp. 45-55. 